\title{
Modern Architecture and Luxury: Aesthetics and the Evolution of the Modern Subject
}

\author{
Joanna Merwood-Salisbury \\ School of Architecture, Victoria University of Wellington, Wellington 6140, New Zealand; \\ joanna.merwood-salisbury@vuw.ac.nz
}

Received: 30 July 2019; Accepted: 31 July 2019; Published: 6 August 2019

\begin{abstract}
A book review of Robin Schuldenfrei, Luxury and Modernism: Architecture and the Object in Germany 1900-1933 (Princeton: Princeton University Press, 2018). This book challenges the canonical interpretation of two of the most revered institutions in the history of modern architecture-the Werkbund and the Bauhaus - and presents a critical interpretation of the relationship between modern architecture and luxury, which first appeared a generation ago.
\end{abstract}

Keywords: architecture; design; luxury; AEG; Werkbund; Bauhaus; Germany; modernism

Luxury and Modernism: Architecture and the Object in Germany 1900-1933 challenges the canonical interpretation of two of the most revered institutions in the history of modern architecture- the Werkbund and the Bauhaus-and presents a critical interpretation of the relationship between modern architecture and luxury, which first appeared a generation ago. In the founding documents of the modern movement, architecture and luxury were framed as irreconcilable opposites. To be modern was to reject ornament—-the traditional aesthetic signifier of social status (Veblen [1899] 1994; Sombart [1913] 1967; Massey 2004). Cheapened by thoughtless application, ornament was seen as wasteful and excessive-a superfluous excrescence to be sloughed off through purifying processes of subtraction and elimination. Framed in terms of social evolution, to take pleasure in ornament was evidence of a primitive or retarded stage of racial development (Loos [1908] 1970; Muthesius [1903] 1994). As Adolf Loos famously expressed in his 1908 essay 'Ornament and Crime', the evolved modern man derived no pleasure from decoration. Emancipated from any fixed social hierarchy, he had no need for conspicuous consumption in order to differentiate himself from his neighbor. However, as this book ably demonstrates, the abandonment of ornament did not necessarily mean the abandonment of luxury; indeed, the discourse of modern architecture in the early decades of the twentieth century turned not on the rejection of luxury but its redefinition. As Schuldenfrei reveals, the term was used in this period to characterize many aspects of modern design. Rather than subtracting form down to its essence, removing design from the aesthetic category of style and the economy of fashion as they claimed, modern architects invented new ways to communicate social status. In these terms, luxury-characterized by the appearance of technical innovation and industrial precision and by material smoothness, shininess, and sleekness-was not abandoned but transformed.

The recognition of luxury as a continuing aspiration of the modern movement began in the 1990s with the reappraisal of architecture's relationship to fashion. Taking a post-structuralist and feminist approach, scholars including Mark Wigley, Mary McLeod, and Frederic J. Schwartz argued that, disguised by ideas of functionalism and objectivity, timelessness and standardization, the logic of fashion continued to dictate the way in which modern architecture was conceived (Wigley 1993, 1995; McLeod 1994; Schwartz 1996; Kinney 1999; Condello 2014). These scholars overturned the narrative of rupture in which modern architecture represented a decisive break with the Victorian era. In doing so, they placed the origins of the modern movement in the eighteenth century, in the period when 
processes of globalization and industrialization produced new markets for luxury (Berg and Eger 2003; Berg 2005). This scholarship revealed an inherent contradiction in the rhetoric of modern architecture: while they sought to control the urban spectacle of commodity culture, modern architects continued to operate within the same framework of production for consumption that they claimed to reject. In this argument, the modernist white wall, and the marble and glass curtain walls that followed, represented the sublimation of ornament into new aesthetic form. In this interpretation, the primary function of modern architecture and design was not to provide new ways of living but, rather, to communicate or express the cultural value of modernity.

With attention turned from production to consumption and signification, related scholarship by Beatriz Colomina and others has recognized the importance of the tools and strategies of advertising and publicity for the modern movement (Colomina 1994; Staniszewski 1998). Consideration of activities formerly considered ancillary to architecture proper (including exhibitions, publications, films, and lectures) has introduced a cohort of new figures into the history of modern architecture, many of them women (McQuaid 1996). Examining the written output of key figures in the canon, others have analyzed the language of the modern movement, concluding that the deployment of concepts of functionalism and objectivity was more often rhetorical than ideological (Benton 2008).

Beautifully produced and illustrated, Luxury and Modernism operates within and expands this theoretical framework. Focusing on architecture and design culture in Germany in the first two decades of the twentieth century, it adds historical depth to recent writing on the social role of luxury (Armitage and Roberts 2016). Given the wide range of people and activities that might be covered under the umbrella of this time and place, Schuldenfrei has necessarily been selective. Rather than broadening the cast of characters included in the canon, she focuses on its central figures. Based on detailed analysis of primary sources, the book re-evaluates the work of three master figures: Peter Behrens, Walter Gropius, and Ludwig Mies van der Rohe. Its method, focusing on their actual practice rather than their stated intentions, is highly revealing. Of all the aspects of German architecture and design in this period, Mies' domestic work for wealthy clients is the most obvious example of luxury reimagined in new materials, forms, and spatial configurations. While Schuldenfrei's analysis of this work is thorough and convincing, the book is strongest when it discusses the products and activities of the Werkbund and the Bauhaus.

Behrens's work with AEG (Allgemeine Elektricitäts-Gesellschaft, or General Electric Company) has always been a primary example of modern architecture's attempt to work closely with industry. Building on the work of earlier Werkbund scholars, Schuldenfrei examines the ways in which Behrens worked directly with existing companies and the environment in which they operated, including the design of architecture, interiors, packaging, and advertising (Schwartz 1996). As she reveals, Behrens created not only modern technical products but also consumer desire, designing electric appliances purposely intended as luxuries, marketed as gifts, and sold via elaborate displays in fashionable stores. While many scholars have explored the role of the exhibition in promoting modern design as exclusive and desirable, Schuldenfrei joins a smaller group looking at the store window as an alternative site for the dissemination of the same message (Lasc et al. 2016). Even those familiar with the Werkbund may not know that it operated a school to train store window designers or that Lilly Reich (Mies' partner in exhibition design) taught at the school. The book includes an absorbing analysis of Werkbund-designed window displays featuring stacks of mass produced, standardized goods. Read against well-known Frankfurt School essays, this section is an original and compelling addition to the scholarship on the aesthetics of mass culture (Benjamin [1936] 2002; Hays 1992). Attention to the store window as a key site of cultural modernization reinforces the argument that not only architects and industrial designers but also new kinds of design professionals (including window dressers) played an important role in creating modern material and visual culture. Through what the American economist Thorstein Veblen described as a process of 'pecuniary emulation', the visibility of aspirational goods in public view would create a taste for such goods on a mass scale (Veblen [1899] 1994). However, as Schuldenfrei concludes, despite claims of universality and affordability, modern architecture and design remained 
a luxury product. Produced by and for elites, it was expensive and appealed only to a small group of people.

Nevertheless, this market-based strategy persisted, even after the political and cultural trauma of the Great War. Although the Bauhaus is often presented as reimagining industrial production as part of a revolutionary social program operating outside the constraints of capitalism, Schuldenfrei's analysis shows that this was not the case. Against the backdrop of the economic crisis that Germany faced in the early 1920s, Gropius, in particular, sought to engage with existing companies and with capitalist investors. Luxury and Modernism contains a detailed reading of the 'Haus am Horn', a model single-family house built for a 1923 exhibition. Designed and publicized as a scalable, mass-produced house, it was in fact punishingly expensive to construct. In order to support the project, Gropius sought funding from leading American financiers, including Henry Ford, John D. Rockefeller, and William Hearst, anticipating the intense engagement between modern architecture and industrial capitalism that came to fruition in the United States after World War II. In this way Luxury and Modernism prompts a reconsideration of the history of modern architecture and design not only in Germany but also across the Atlantic. For example, the 1929 International Style Exhibition at the Museum of Modern Art in New York, in which the work of Gropius and Mies featured prominently, is a key event in architectural history (Staniszewski 1998; Stritzler-Levine 2006; Riley and Sacks 2009). The canonical interpretation of this exhibition is that the curators, Henry-Russell Hitchcock and Philip Johnson, denuded the modern style of its socialist context and misrepresented the intentions of its European creators. In emphasizing how the Werkbund and Bauhaus worked in concert with industrial capitalism, Schuldenfrei's research complicates that narrative.

The final section of Luxury and Modernism deals with a broader question: who were the subjects of modern luxury? The book concludes with a fascinating insight into the real (rather than the projected or imagined) subjects of modern architecture through close analysis of some of Mies' early domestic clients. Industrialists living in the leafy western suburbs of Berlin, these patrons had the sensibility to appreciate his luxurious use of modern materials and the money to purchase his lavish designs. While the detailed examination of lesser-known projects, such as the Lange and Estes Houses in the wealthy suburb of Krefeld, is interesting (and the contemporary photographs are beautiful), the argument that Mies' domestic work constitutes luxury reimagined in new terms is already well established. The book is more suggestive when it touches on the broader meaning of urban living for early-twentieth-century Europeans, for whom modern life was inextricably associated with the emergence of modern cities. Building on Neumeyer's work, Schuldenfrei unpacks Mies' understanding of urban dwellers as a privileged class, living autonomous lives directed by individual will and self-determination (Neumeyer 1991). As he imagined it, apartment living offered the opportunity for mobility and self-realization, freed from the constraints of social convention, from family ties, and from the need to labor over everyday chores (needless to say, this was especially significant for women).

Famously, this celebration of unshackled cosmopolitanism, of internationalism, came under attack around 1930. Members of the Nazi party considered modern art and architecture 'degenerate' - expressive of a rootlessness and social liberalism that they associated with the Jewish race and culture (Lane [1968] 1985; Koehler 2002). In its place, the party promoted folk art and architecture, along with neo-classicism, as the best representation of native German values. Under extreme political pressure, Mies and his staff were forced to close the Bauhaus in 1933. This moment marks the end of the period covered by Luxury and Modern Architecture. Though the book does not consider it, the Nazi condemnation of the Bauhaus is perhaps worthy of further discussion, highlighting as it does the relationship between modern architecture and luxury as a signifier of difference. In one sense, Nazi aesthetic philosophy (based on an explicit belief in racial superiority and a fear of racial degeneration) sat in opposition to the trans-national principles promoted by the Bauhaus. The discourse of modern architecture claimed to eliminate the material expression of difference via the universal adoption of principles of functionalism and objectivity. However, the theory of modern architecture that emerged in Europe in the mid- to late-nineteenth century depended on another kind of difference-a belief 
in the unequal progress of human development across races. The existence of a modern style was contingent on the counterexample of artifacts and people classified as non-modern, uncivilized, and primitive (Cheng et al. 2017). Over time, the characteristics of modernity-rationality, inventiveness, and technological know-how-that had been associated with European (particularly Germanic) races were stripped of their explicitly racist terminology and sublimated into a purportedly international style. As Schuldenfrei notes, in Germany the category of modern luxury arose in the context of a desire to expand German markets globally in an era of imperial expansion and colonization. In competition for those markets, each of the industrialized nations was anxious to proclaim its design products the most advanced and sophisticated. Behrens's electric appliances, Gropius' ideal houses, and Mies' sleek, transparent apartments expressed alternative versions of that sophistication. Embodied in architecture and design, modern luxury created a new form of social distinction, not between aristocrats and plebes, upper and lower class, rich and poor, but between evolved and less evolved peoples. Manifesting the aesthetic perfection of industry and technology, it signified the political and economic ascendance of western Europe.

Funding: This research received no external funding.

Conflicts of Interest: The author declares no conflict of interest.

\section{References}

Armitage, John, and Joanne Roberts. 2016. Critical Luxury Studies: Art, Design, Media. Edinburgh: Edinburgh University Press.

Benjamin, Walter. 2002. The Work of Art in the Age of its Technical Reproducibility. In Walter Benjamin: Selected Writings. Volume 3, 1935-1938. Edited by Howard Eiland and Michael W. Jennings. Cambridge: Belknap Press of Harvard University Press, pp. 101-33. First published 1936.

Benton, Tim. 2008. The Complexities and Contradictions of Modernism. Positions 0: 16-21.

Berg, Maxine. 2005. Luxury and Pleasure in Eighteenth-Century Britain. London: Oxford University Press.

Berg, Maxine, and Elizabeth Eger, eds. 2003. Luxury in the Eighteenth Century. Debates, Desires and Delectable Goods. London: Pallgrave Macmillan.

Cheng, Irene, Charles L. Davis, and Mabel O. Wilson. 2017. Racial Evidence. Journal of the Society of Architectural Historians 76: 440-42. [CrossRef]

Colomina, Beatriz. 1994. Publicity and Privacy: Modern Architecture as Mass Media. Cambridge: MIT Press.

Condello, Annette. 2014. The Dispersal of Modern Luxury. In The Architecture of Luxury. Farnham: Ashgate Publishing, pp. 115-44.

Hays, K. Michael. 1992. Modernism and the Posthumanist Subject. Cambridge: MIT Press.

Kinney, Leila W. 1999. Fashion and Fabrication in Modern Architecture. Journal of the Society of Architectural Historians 58: 472-81. [CrossRef]

Koehler, Karen. 2002. The Bauhaus, 1919-1928: Gropius in Exile and the Museum of Modern Art, N.Y., 1938. In Art, Culture and Media under the Third Reich. Edited by Richard Etlin. Chicago: University of Chicago Press, pp. 287-315.

Lane, Barbara Miller. 1985. Architecture and Politics in Germany, 1918-1945. Cambridge: Harvard University Press. First published 1968.

Lasc, Ana I., Patricia Lara-Betancourt, and Margaret Maille Petty, eds. 2016. Architectures of Display: Department Stores and Modern Retail. London: Routledge.

Loos, Adolf. 1970. Ornament and Crime. In Programs and Manifestoes on 20th-Century Architecture. Edited by Ulrich Conrads. Cambridge: MIT Press, pp. 19-24. First published 1908.

Massey, Jonathan. 2004. New Necessities: Modernist Aesthetic Discipline. Perspecta 35: 112-33.

McLeod, Mary. 1994. Undressing Architecture: Fashion, Gender and Modernity. In Architecture: In Fashion. Edited by Deborah Fausch, Paulette Singley, Rodolphe El-Khoury and Zvi Efrat. New York: Princeton Architectural Press, pp. 38-123.

McQuaid, Matilda. 1996. Lilly Reich: Designer and Architect. New York: The Museum of Modern Art/Harry N. Abrams. 
Muthesius, Hermann. 1994. Style-Architecture and Building-Art: Transformations of Architecture in the Nineteenth Century and Its Present Condition. Edited by Stanford Anderson. Santa Monica: Getty Center for the History of Art and the Humanities. First published 1903.

Neumeyer, Fritz. 1991. The Artless World: Mies van der Rohe on the Building Art. Cambridge: MIT Press.

Riley, Terence, and Joshua Sacks. 2009. Philip Johnson: Act One, Scene One-The Museum of Modern Art? In Philip Johnson. The Constancy of Change. Edited by Emmanuel Petit. New Haven: Yale University Press, pp. 60-67.

Schwartz, Frederic J. 1996. The Werkbund: Design Theory and Mass Culture before the First World War. New Haven and London: Yale University Press.

Sombart, Werner. 1967. Luxury and Capitalism. Ann Arbor: University of Michigan Press, pp. 59-60. First published 1913.

Staniszewski, Mary Anne. 1998. The Power of Display: A History of Exhibition Installations at the Museum of Modern Art. Cambridge: MIT Press.

Stritzler-Levine, Nina. 2006. Curating History, Exhibiting Ideas: Henry-Russell Hitchcock and Architectural Exhibition Practice at the MoMA. In Summerson and Hitchcock: Centenary Essays on Architectural Historiography. Edited by Frank Salmon. New Haven and London: Yale University Press, pp. 34-35.

Veblen, Thorstein. 1994. The Theory of the Leisure Class. London: Penguin Books. First published 1899.

Wigley, Mark. 1993. White Out: Fashioning the Modern. Assemblage 22: 6-49. [CrossRef]

Wigley, Mark. 1995. White Walls, Designer Dresses: The Fashioning of Modern Architecture. Cambridge: MIT Press.

(C) 2019 by the author. Licensee MDPI, Basel, Switzerland. This article is an open access article distributed under the terms and conditions of the Creative Commons Attribution (CC BY) license (http://creativecommons.org/licenses/by/4.0/). 